\title{
Having an Impact: Think Tanks and the NATO Enlarge- ment Debate
}

\author{
Ronald D. Asmus ${ }^{1}$
}

There are moments in the evolution of U.S. foreign policy where think tanks have had a decisive influence in reshaping conventional wisdom and setting a new course on a key strategic issue. The debate over NATO enlargement in the early 1990s was one of those moments. U.S. think tanks played a key role in developing and building support for the U.S. decision to enlarge NATO as part of a broader strategy of overcoming the continent's Cold War divide and building a Europe whole and free and at peace. It was a dramatic period. The collapse of communism in Central and Eastern Europe in 1989, and the disintegration of the Soviet Union itself two years later, had also left in its wake a vacuum in terms of Western policy in the region. The democratic revolutions of 1989 in Central and Eastern Europe had taken the West largely by surprise and, as welcome as they were, they nonetheless overturned many of the underlying assumptions that had previously guided Western thinking and policy.

Events on the ground were outpacing the ability of many policy-makers to rethink their paradigms. Western governments and bureaucracies were at times behind the curve of history - and they knew it—victims, in a sense, of our own success. Having succeeded in toppling communism without a shot fired in confrontation between East and West, the West was unprepared politically and intellectually to produce a new vision of what kind of post-Cold War Europe and trans-Atlantic relationship was needed for the future. What was NATO's purpose in a world without communism and a Soviet threat? These questions produced one of the most passionate and divisive foreign policy debates of the 1990s in the U.S. The issue was not only whether or not to enlarge NATO to include Central and Eastern Europe, a question that was in many ways just the tip of the iceberg. Policy-makers were also battling over nothing less than what kind of Europe and U.S.-European relationship the United States should build for the new era. The result was some of the most far-reaching changes in U.S. and NATO strategy in decades. I was fortunate to have a bird's-eye view of this debate, first as a RAND analyst, subsequently as a deputy assistant secretary of state in the European Bureau, and later as a senior fellow at the Council on Foreign Relations.

Why did think tanks play such a key role in this debate? There were several reasons.

First, in the early 1990s there was a keen demand for fresh and outside-thebox thinking on both sides of the Atlantic, and governments were often not well

\footnotetext{
${ }^{1}$ Dr. Ronald D. Asmus is Senior Transatlantic Fellow, German Marshall Fund of the United States.
} 
equipped to provide it. Coping with revolutionary change or coming up with new intellectual paradigms are not the natural strengths of bureaucracies. This is not because people working inside the system are less gifted, but because they must operate by consensus, are at times risk-averse, and are simply overloaded with short-term operational issues and requirements. It is much easier to think big or outside the box when one is on the outside and at a think tank where the incentive structure is very different. Former Secretary of State Henry Kissinger's remark that one should accrue one's intellectual capital before entering government because one only depletes it while working in the bureaucracy is, unfortunately, often the case.

Second, in the early 1990s the initial efforts of the U.S. government to grapple with these issues had left it seriously divided. Many actors in the U.S. government at the time turned to outsiders for additional input and analysis. In some cases this was done simply to further strengthen their own cases. In others it reflected efforts to find new ways to bridge existing differences across the inter-agency process. The net result was that senior U.S. officials proactively increasingly reached out to think tanks and brought them into normally closed interagency deliberations.

Third, some think tanks were able to capitalize on these opportunities because they brought some unique strengths and assets to the table. In the early 1990s, RAND, based in Santa Monica, had one of the strongest teams of European security experts outside of the U.S. government. In addition to a close working relationship with different parts of the government, it also had excellent contacts in Western and Central and Eastern Europe, as well as Russia. Along with the National Defense University and the Atlantic Council, it had been among the first think tanks on the ground in the new democracies of Central and Eastern Europe. Indeed, the German leadership as well as various Central and East European governments had turned to these institutes for analytical support in developing new polices. This gave RAND analysts access and insights into the thinking in Washington and in both halves of Europe that few outsiders enjoyed.

But access alone was not enough. In an age where the work and analysis of some think tanks are increasingly partisan and political, it is important to underscore that institutions like RAND were successful precisely because they went that extra mile to remain analytical and objective. They were able to provide busy and overworked senior policy-makers what they often needed most: a framework and a method for thinking through a problem as well as a set of options, complete with their pros and cons. In Washington, alternative policy views are a dime a dozen, but those pieces of research that help provide a new analytic framework are few and far between. For example, the most successful analytical work RAND produced during the NATO enlargement debate was not the op-eds or other advocacy pieces individuals wrote. Rather, it was a series of analytical briefings that explored alternative rationales for enlarging the Alliance, the practical issues surrounding how it could be done, the costs thereof, and the implications for Russia 
and other countries not included. As an institution, RAND never took an official stance for or against on NATO enlargement. It saw its role first and foremost as assisting policy-makers in understanding the issues, options, and tradeoffs-and letting them make better-informed decisions of their own.

This did not mean that individual analysts did not have strong views. They often did; I was among the earliest and most outspoken advocates of enlargement. But many of my RAND colleagues were on the other side of the issue. Indeed, at times we ended up testifying on opposite sides before Congress. Internal RAND seminars or board meetings at the time were as contentious, and witnessed debates as passionate, as any inter-agency meeting. But it was RAND's ability to frame the issues and to elucidate the trade-offs involved that earned it the most praise from policy-makers. Perhaps the greatest compliment I received came from a senior Department of Defense official strongly opposed to NATO enlargement who praised a briefing my colleagues and I had done as the best piece of analysis he had seen that helped him understand the linkages and trade-offs of the issues, even though the two of us came to completely different conclusions as to what U.S. policy at the time should be.

As a result, a number of think tanks became, for a period of time, an informal but nonetheless real part of an extended inter-agency process and debate within the U.S. government on NATO's future. Their briefings and memos became an integral part of the intellectual and policy debate. Think-tank analysts worked closely with senior officials, and were often invited in to give briefings. They were often asked to cross the Atlantic and test-market ideas and policy options with West European allies or Central European partners in order to provide feedback before final decisions were made in Washington. By the mid-1990s, the role of think tanks in the NATO enlargement debate was changing. The debates within the U.S. government had been substantially resolved, but the broader public debate over NATO enlargement was just starting. As the enlargement issue became the focal point of an increasingly passionate debate, other think tanks stepped in to help provide a forum for broader public discussion. The Council on Foreign Relations, the Brookings Institution, and the "New Atlantic Initiative" of the American Enterprise Institute all stepped forward to create study groups and other outlets for public discourse and debate. Rarely has an issue been the subject of more attention and public policy debate as NATO enlargement was in the mid- and late 1990s.

The role of think tanks changed to reflect these new realities. They remained crucial in terms of shaping the broader debate and building public understanding of and support for new policies. But they were no longer playing a quasi-insider's role or acting as a key driver in that process. Nonetheless, many key officials from the early and mid-1990s—such as Secretary of State Warren Christopher, Deputy Secretary of State Strobe Talbott, and U.S. Ambassador to the United Nations Richard Holbrooke- have testified to the important role that outside think tanks played in helping them develop their own thinking on these issues. 


\section{THE QUARTERLY JOURNAL}

Looking back today, what can one learn from this period and the crucial role that think tanks played in helping to develop U.S. and NATO policy? To what degree was the impact of think tanks the result of a unique phase of history, where senior policy-makers who were seeking outside support to come to terms with revolutionary change encountered the entrepreneurial skills of several think tanks? Or does this experience teach us something more enduring about policymaking in the modern age? The simple fact is that in today's globalizing world, the pace of diplomacy is accelerating while the internal ability of governments to think long-term and conceptually continues to decrease. This trend is further exacerbated in the U.S. by the long-term under-funding of the State Department. In practical terms, this has meant that whatever resources exist on paper for longerterm strategic planning are often de facto pressed into service to simply manage the day-to-day operational workload. Often there is little if any time left over for other tasks. As a political appointee coming to government from the think-tank world, I was surprised to discover how the need to manage day-to-day operational needs often crowded out efforts to devote more energy to longer-term intellectual thinking. Moreover, policy and planning staffs or cells are increasingly less able to play the role initially envisaged for them. The days when a veteran diplomat like George Kennan could spend weeks on a paper that would then be systematically discussed and perhaps set U.S. policy are gone, perhaps forever.

This suggests that the demand from within government for creative thinking from the outside is likely to continue, and may even increase. To be sure, the early 1990s in Europe were an extraordinary phase, when revolutionary changes called so many firmly-held assumptions into question. But in the future there will be other issues or parts of the world where major changes on the ground are likely to render existing policies obsolete. As long as governments suffer from a limited internal capacity to do long-term strategic planning, they will continue to reach out to the think-tank world for research and ideas they can tap into and exploit. Whether future think tanks will be able to step in to fill that need is a separate question. On the one hand, many think tanks have gotten smarter. And the market is increasingly competitive. As competition among think tanks grows over influence on official policy, it has bred a new generation of entrepreneurial analysts who assiduously cultivate their government contacts to obtain unique access. But getting in the door is only half the battle. At the end of the day the key to success is the quality of one's work, the ability to address the needs of senior policy-makers, and the packaging of practical policy recommendations. 